\title{
Effect of combination of dye carotene and phycocyanin using daucus carota and spirulina sp. on optical sensor performance
}

\author{
Rahmadwati $^{1}$, Luthfiyah Rachmawati ${ }^{2}$, Panca Mudjirahardjo ${ }^{3}$, Eka Maulana ${ }^{4}$ \\ 1,3,4 Department of Electrical Engineering, Engineering Faculty Brawijaya University, Indonesia \\ ${ }^{2}$ Department of Materials Science and Engineering, National Cheng Kung University, Taiwan
}

\begin{tabular}{l} 
Article Info \\
\hline Article history: \\
Received Jun 15, 2019 \\
Revised Aug 16, 2019 \\
Accepted Aug 30, 2019 \\
\hline
\end{tabular}

Keywords:

Dye carotene

Dye phycocyanin

Optical sensor

Spin coating

\begin{abstract}
This research designed optical sensors using mercury lamp of $160 \mathrm{~W}$. These sensors provided voltage and current output. The design of optical sensors used the organic based material, i.e. dye carotene and phycocyanin. Fabrication of optical sensor in this research used spin coating deposition method. Based on the results of absorbance test, dye carotene had the largest absorption of light of 2.882 (a.u). Dye phycocyanin at length had the largest absorption of light of 2.787 (a.u). Combination between dye carotene and phycocyanin, for a 3: 1 (Carotene: Phycocyanin) ratio had a waveform like a dye carotene with a peak of 2.587 (au), whereas for $1: 3$ had a waveform like phycocyanin with a peak of 2,279 (au). But, sample 1: 1 ratio had decrement the light absorbance rate with peaks of 1.183 (au). At the voltage testing result, combination of phycocyanin: carotene (1:3) had the best linearity. The response time of dye 3:1 (phycocyanin: carotene), 1:1, 1:3, phycocyanin, and carotene were $6.72 \mathrm{~s}, 2.469 \mathrm{~s}, 1.171 \mathrm{~s}, 2.66 \mathrm{~s}$ and $7.01 \mathrm{~s}$ respectively.
\end{abstract}

Copyright @ 2020 Institute of Advanced Engineering and Science. All rights reserved.

\section{Corresponding Author:}

Rahmadwati,

Department of Electrical Engineering,

Engineering Faculty, Brawijaya University,

Jalan MT Haryono 167, Malang 65145, Indonesia.

Email: rahma@ub.ac.id

\section{INTRODUCTION}

Today, the use of renewable energy is being developed, such as wind energy, solar energy, hydro energy, biomass, geothermal, hydrogen and fuel cell. Solar energy is one of renewable energy that is free, sustainable, inexhaustible and non-polutting resources. Regarding to develop solar energy, there was a device that needed for measure the light energy called sensor. A number of research work on sensor, however the sensor are made from inorganic material. In order to support the renewable energy that environmental friendly, organic devices are developed. This signified that there was a shift in research and development that was originally based on conventional inorganic materials, such as silicon to organic matter [1]. One type of electronic component that was being developed was a sensor. Sensor technology was a technology that played an important role in various fields for monitoring, process control, and security [2]. The optical sensor was one sensor that was often implemented for automatic lamp settings as energy savings. However, optical sensor on the market used cadmium sulfide semiconductor materials. Cadmium sulfide or sulfur, in excess concentration, was toxic and detrimental. For that reason, it needed to be replaced with organic matter [3].

To develop the solar energy technology, an optical sensor is needed that measure the light energy and convert to electricity. The number of researches work on optical sensor such as the optical sensor that are designed widely used in the field of energy savings [4, 5], image sensor [6, 7], light monitoring [8, 9], biochemical [10,11], biomedical [12] and other applications [13-15]. However the price of optical sensor is expensive and few of research work on organic optical sensor. Indonesia had extensive forests with various resources. There were various kinds of flowers, fruits and other plants. Plants could be sources of natural 
dyes. Dyes in plants were used to absorb sunlight in photosynthesis. In the making of organic dye optical sensor, it could function as a medium for absorption of photon energy. To reduce the cost of optical sensor and utilize the natural resoources, it possible to develop the optical sensor based on organic material. The researcher investigated optical sensor from the development of Dye Sentized Solar Cell using variation of dye that apply $\mathrm{TiO}_{2}$ as the active layer $[16,17]$. The result is the $\mathrm{TiO}_{2}$ has attractive oxide semiconductor for DSSC, it can be conclude that it suitable for sensor applications [18]. The previous research regarding optical sensor based on dye sensitized solar cell (DSSC) based on tobacco chlorophyll have been delivered [19-21]. The DSSC are designed varied in size, in order to know the quality of light absorption. Furthermore, the sensor were measured with different light illuminance and different temperature. It shown higher electrical parameter output both current and voltage. However, in term of influence temperature radiation to output voltage, in current temperature did not give significant result to the output voltage. It because the temperature rise increasingly affect to the tobacco dye structure. The quality of the substrate will be decrease. Continually, it did not give good performance in electrical parameter. Considering the research conducted by Nurhayati and Suendo [1] in 2011, stated that the combination of several pigments could improve dye absorption performance. This inspired the researcher to take advantage of the potential that existed in the environment by conducting a research on optical sensors with organic materials, such as daucus carota or carrots. Carotene has a carboxylic group at the end of its compound chain which allows it to be able to bind to the $\mathrm{TiO} 2$ surface. All carotenoids are polyisoprenoids that have systems with single and double conjugated bonds [22]. Carrots had carotene which absorption range at wavelengths of $442-472 \mathrm{~nm}$ [23]. Phycocyanin is a protein-pigment complex that is interconnected and involved in light harvesting and transduction energy. Phycocyanin is the most pigment in blue-green algae, and the amount of it is more than $20 \%$ dry weight of algae. Phycocyanin is the dominant pigment in Spirulina [24]. The content of phycocyanin in Spirulina tablets $500 \mathrm{mg}$ is as much as $333.0 \mathrm{mg}$ [25]. Therefore, the making of light sensor from carrots would be combined with phycocyanin pigments obtained from Spirulina sp with wavelength absorption range of 450 $650 \mathrm{~nm}[26]$.

This study presents the design of optical sensor based on combination carotene and phycocyanin using daucus carota or carrot and spirulina. So it will combine the pigmens of colour yellow/orange from carrots dan green-blue from spirulina. In this research, the optical sensors are designed in five combination of both materials: phycocyanin (P);carotene (C); P3C1 (3:1 phycocyanin: carotene), P1C1 (1:1 phycocyanin: carotene), P1C3 (1:3 phycocyanin: carotene). It aims to know the performance of optical sensor that good in light absorption as a medium for absorption of photon, the ability to produces higher electrical parameter output both current and voltage.

\section{RESEARCH METHOD}

There are several steps to be completed in order to design the optical sensor based on combination material of carotene and phycocyanin that is shown in Figure 1. The explanation regarding design and measure the performance of optical sensor-based carotene and spirulina as follows:

\subsection{Designing Optical Sensor}

The design of the Transparent Conductive Oxide (TCO) glass design in this research is varied with the variation of dye phycocyanin and carotene that are uniform in shape and area. It also given the same treatment in testing. The design of the TCO glass dye variation phycocyanin and carotene is shown in Figure 2. In this research, the optical sensors are designed in five combination of both materials: phycocyanin (P);carotene (C); P3C1 (3:1 phycocyanin: carotene), P1C1 (1:1 phycocyanin: carotene), P1C3 (1:3 phycocyanin: carotene).

In this research, in order to design optical sensor use some materials included $\mathrm{TiO}_{2}$ powder, Polyvinyl Alcohol (PVA) and aquades. $\mathrm{TiO}_{2}$ paste uses for deposition into $\mathrm{TCO}$ glass. $\mathrm{TiO} 2$ powder mixed with 1.5 grams PVA that has been added $13.5 \mathrm{ml}$ aquades. All the material is stirred use magnetic stirrer in $80^{\circ} \mathrm{C}$ during 30 minutes until the solution become thicken and homogen. This solution is called binder solution. Next step, the binder solution is mixed with 0.5 -gram $\mathrm{TiO} 2$ powder. The spin coating method is chosen in this process where $\mathrm{TiO} 2$ paste is coated into TCO. Spin coating is a method coating disposition in order to distribute the liquid using high speed rotation $(1000 \mathrm{rpm})$. Firing process using electrical furnace, the temperature is sets to $250^{\circ} \mathrm{C}$ for 30 minutes. It aims to obtain the perfect attachment between $\mathrm{TiO} 2$ and TCO glass. Continually, making dye carotene and phycocyanin. Dye carotene is produced from carrot extract. Carrots are washed using distilled water and peeled. After that, The carrot are grated and weighed as much as 40 grams. Then, it put in a glass breaker which contains $50 \mathrm{ml}$ of $\mathrm{n}$-hexane and covered with aluminum foil. Carrot and n-hexane are stirred in a temperature of $45^{\circ} \mathrm{C}$ for 30 minutes. The next step is to 
separate the extract from carrot pulp. Filtering the extract is done using filter paper, so the carotene substance to be completely separated from the grated carrot.

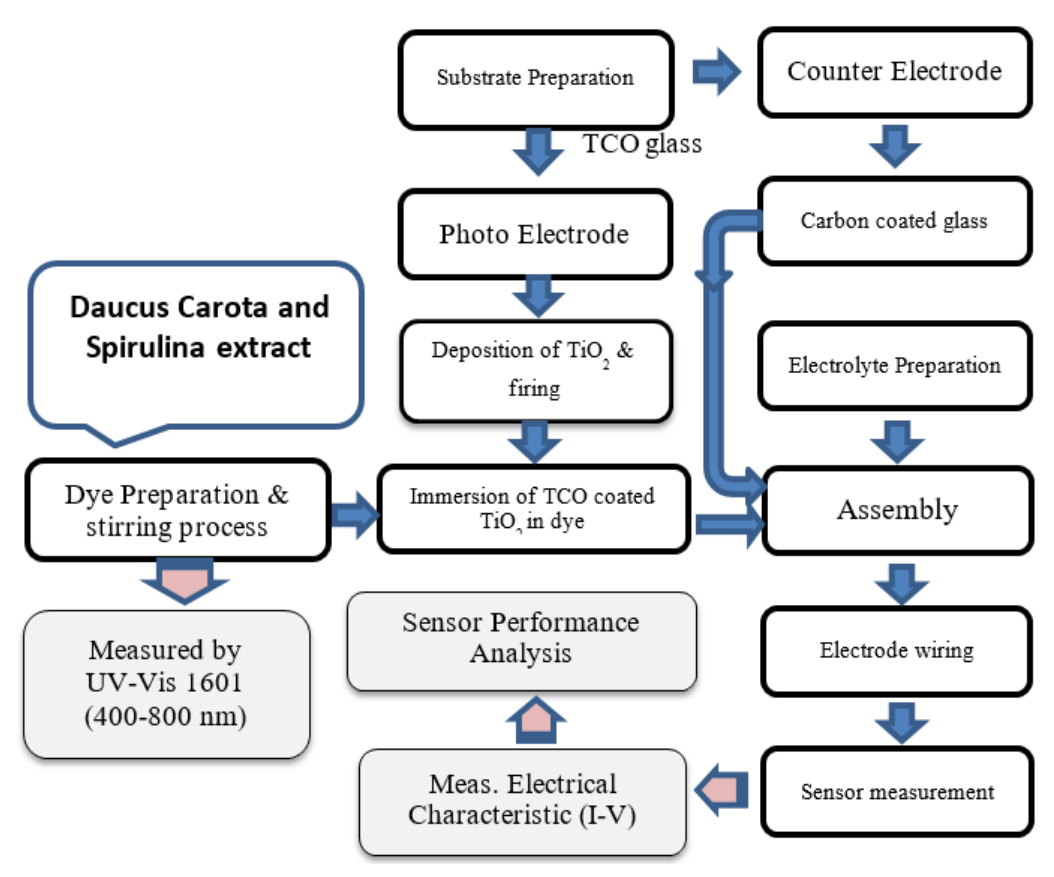

Figure 1. Flowchart of sensor design

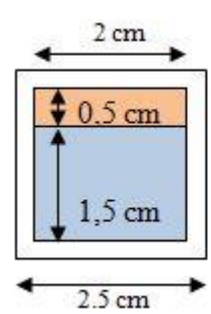

(a)

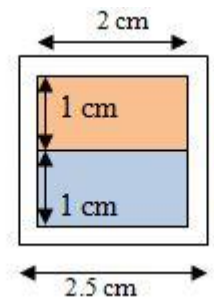

(b)

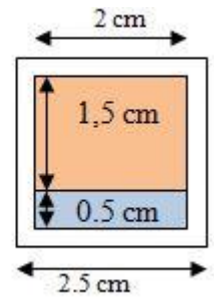

(c)



(d)

(e)

Figure 2. Sample of TCO design, (a) P3C1 (3:1 phycocyanin: carotene), (b) P1C1 (1:1 phycocyanin: carotene), (c) P1C3 (1:3 phycocyanin: carotene), (d) P (phycocyanin) dan (e) C (Carotene)

As for dye phycocyanin, it is produced from Spirulina Sp. powder. Spirulina is weighted as much as 1.6 grams and dissolved in $40 \mathrm{ml}$ of ph 7 phosphate buffer and then homogenized using a magnetic stirrer for 2 hours. The solution is stored at $5^{\circ} \mathrm{C}$ for 24 hours. After that, the solution is filtered using filter paper. The filter results obtained are solid blue, and then the solution is centrifuged at a speed of $3500 \mathrm{rpm}$ at $5^{\circ} \mathrm{C}$ for 30 minutes. The centifuse results that are used in here as dye are supernatants, while pellets are not used. Continually, $\mathrm{TiO}_{2}$ layer is then immersed in dye solution for approximately 1 hour. In this process, there is an absorption of dye phycocyanin and carotene to the surface of $\mathrm{TiO}_{2}$. In order to making opposite electrodes has been done by heating the conductive side of the TCO glass to the flame of the candle for about 1 minute. The last step is giving electrolyte solution, in this process, $0.25 \mathrm{ml}$ electrolyte solution is dropped in the $\mathrm{TiO} 2$ paste layer which has been immersed in dye.

\subsection{Sensor Assembly}

When assembling this optical sensor, TiO2 paste coated TCO glass which has been immersed in dye functions as an anode (photoelectrode). Dye that permeated in $\mathrm{TiO} 2$ paste functions as absorbing sunlight. The TCO glass used as the opposite electrode functions as a cathode. In order for the process of changing sunlight into electricity to be faster, electrolytes are needed as electron transfers. The sensor results are shown in Figure 3. 


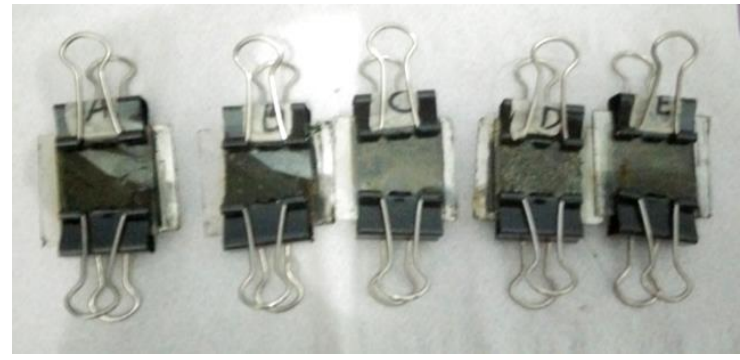

Figure 3. The result of optical sensor from left to the right respectively. Sample A (Phycocyanin), B (Carotene), C (Phycocyanin: Carotene 3:1), D (Phycocyanin: Carotene 1:1), dan E (Phycocyanin: Carotene 1:3)

\section{RESULTS AND ANALYSIS}

This absorbance test aims to determine the ability level of dye that has been combined in absorbing light in a wavelength spectrum between $300 \mathrm{~nm}$ and $800 \mathrm{~nm}$. In this test, a Visible UV-VIS Spectrophotometer is used with type UV-1800 from Shimadzu. Each sample is tested at a wavelength of $300 \mathrm{~nm}$ to $800 \mathrm{~nm}$. The sample absorbance test results are shown in Figure 4.

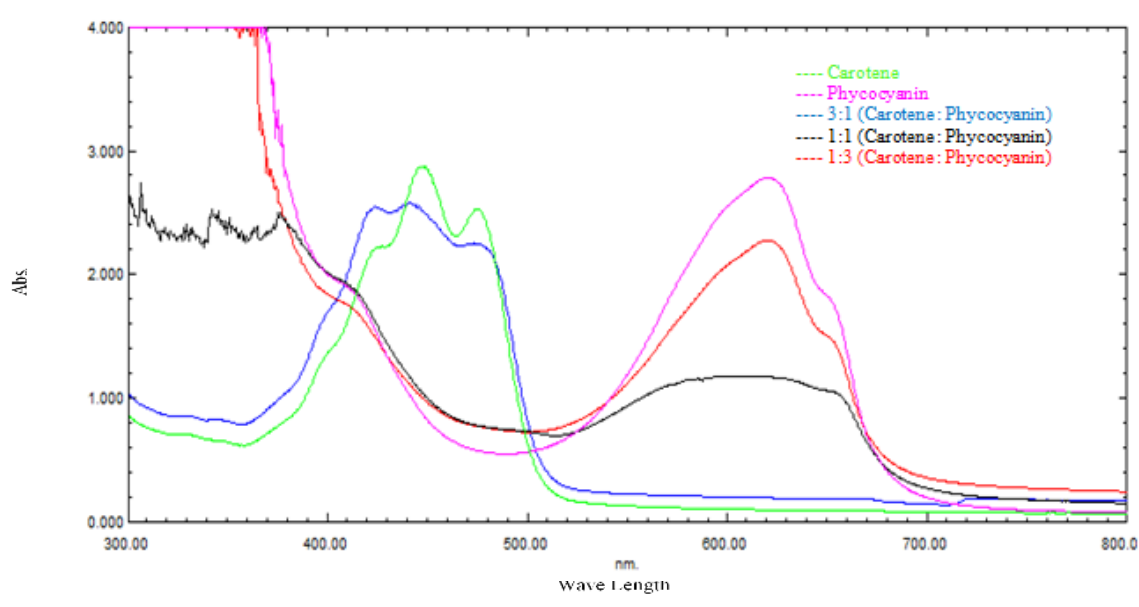

Figure 4. The result of absorbance test

In Figure 4, it can be seen that at a wavelength of $400 \mathrm{~nm}$ to approximately $494 \mathrm{~nm}$ the dye carotene has the greatest absorbance or light absorption of 1 (au) to 2.882 (highest) at $449 \mathrm{~nm}$ at 2.882 (au) and $474 \mathrm{~nm}$ at $2.531(\mathrm{au})$. Dye phycocyanin in length has a peak at $620.50 \mathrm{~nm}$ of $2.787(\mathrm{au})$ with an increase occurring at $500-620.50 \mathrm{~nm}$ and decreasing at $620.50-700 \mathrm{~nm}$ and $300-500 \mathrm{~nm}$. For a combination of dye carotene and phycocyanin, for a ratio of 3:1 (carotene: phycocyanin ) has a waveform like dye but carotene, but the wave peak at $440.50 \mathrm{~nm}$ is 2.587 (au), while for 1: 3 it has a waveform like phycocyanin with a peak of 2,279 (au) at $620.50 \mathrm{~nm}$. However, mixing two dyes with a ratio of 1: 1 has decreased the absorbance rate of light with a peak of 1,183 (au) at a wavelength of $614 \mathrm{~nm}$. This happens because of the different characteristics of two dye solutions. Dye Phycocyanin is polar and carotene is non-polar, so it cannot be homogeneous and weaken each other in each dye.

\subsection{Voltage Test Results}

Based on the average value, the results of four voltage test is shown in a graph in Table 1. The voltage values in Table 1 are the average voltage values in 4 (four) measurements. The value of the sensor voltage with dye phycocyanin is $48.25 \mathrm{mV}$, while carotene is $18.925 \mathrm{mV}$. The sensor that contains variation of dye phycocyanin and carotene, sample 3: 1 (phycocyanin : carotene) has a greater voltage of $35.475 \mathrm{mV}$ compared to 1: 1 with a voltage of $16.85 \mathrm{mV}$ and $1: 3$ with a voltage of $18.925 \mathrm{mV}$ at illumination of 5000 lux. The larger the lux, the greater the sensor voltage. 
Table 1. Optical Sensor Voltage Test Results with Dye Variations Carotene and Phycocyanin

\begin{tabular}{ccccccc}
\hline \multirow{2}{*}{ Temperature $\left({ }^{\circ} \mathrm{C}\right)$} & Ilumination $(\mathrm{Lux})$ & $\mathrm{P} 3 \mathrm{C} 1$ & $\mathrm{P} 1 \mathrm{C} 1$ & $\mathrm{P} 1 \mathrm{C} 3$ & $\mathrm{P}$ & $\mathrm{C}$ \\
\hline 27,3 & 30 & 6,475 & 4,825 & 5,475 & 14,45 & 6,225 \\
30 & 2500 & 30,525 & 12,45 & 8,425 & 42,95 & 13,15 \\
31 & 2700 & 32,25 & 13,75 & 9,375 & 45,275 & 14,15 \\
31,8 & 2800 & 33 & 14,45 & 9,875 & 46,375 & 14,725 \\
32 & 2900 & 33.6 & 15,025 & 10,3 & 46,95 & 15,05 \\
33,5 & 3100 & 33,875 & 15,325 & 10,75 & 46,625 & 15,875 \\
34,7 & 3700 & 34.5 & 16,125 & 11,6 & 47,85 & 17,15 \\
35,1 & 3900 & 34,675 & 16,45 & 11,825 & 48,1 & 17,575 \\
36,9 & 4700 & 35,125 & 16,675 & 12,975 & 48,375 & 18,775 \\
37 & 4800 & 35,275 & 16,7 & 13,075 & 48,1 & 18,9 \\
37,1 & 5000 & 35,475 & 16,85 & 13,225 & 48,25 & 18,925 \\
\hline
\end{tabular}

\subsection{Current Test Results}

Based on the average value, the results of four current tests is shown in a graph in Table 2.

Table 2. The Result of Current Test with the Variation of Dye Carotene and Phycocyanin

\begin{tabular}{ccccccc}
\hline \multirow{2}{*}{ Temperature $\left({ }^{\circ} \mathrm{C}\right)$} & \multirow{2}{*}{ Ilumination (Lux) } & P3 C1 & P1 C1 & P1 C3 & P & C \\
\hline 27,3 & 30 & 0,3 & 0,85 & 0,125 & 0,975 & 0,1 \\
30 & 2500 & 1,1 & 1,825 & 0,475 & 2,6 & 0,725 \\
31 & 2700 & 1,25 & 1,975 & 0,525 & 2,8 & 0,85 \\
31,8 & 2800 & 1,3 & 1,975 & 0,525 & 2,875 & 0,9 \\
32 & 2900 & 1,35 & 1,95 & 0,525 & 3,025 & 0,9 \\
33,5 & 3100 & 1,4 & 2 & 0,5 & 3,15 & 0,875 \\
34,7 & 3700 & 1,575 & 2,15 & 0,5 & 3,55 & 0,9 \\
35,1 & 3900 & 1,6 & 2,2 & 0,5 & 3,65 & 0,875 \\
36,9 & 4700 & 1,65 & 2,425 & 0,55 & 4,175 & 0,9 \\
37 & 4800 & 1,7 & 2,475 & 0,575 & 4,225 & 0,9 \\
37,1 & 5000 & 1,7 & 2,5 & 0,575 & 4,325 & 0,925 \\
\hline
\end{tabular}

In Table 2 , the current sensor value with dye phycocyanin is $4,325 \mu \mathrm{A}$, while Carotene $0.925 \mu \mathrm{A}$. A sensor that has variations in dye concentration phycocyanin and carotene, sample 1:1 (phycocyanin:carotene) has a larger current of $2.5 \mu \mathrm{A}$ compared to 3: 1 with a voltage of $1.7 \mu \mathrm{A}$ and $1: 3$ with a voltage of $0.575 \mu \mathrm{A}$ at 5000 lux illumination.

The greater the light illumination, the greater the sensor current. The voltage and current test results are shown in Table 3. Based on Table 3, the coefficient of determination $\left(\mathrm{R}^{2}\right)$ which is close to the value of 1 indicates that the illumination greatly affect the output voltage and current optical sensors. In voltage testing, optical sensor with dye 1: 3 (phycocyanin : carotene ) has a higher degree of linearity than other sensors. In testing the output current, the highest linearity is found in the optical sensor with dye phycocyanin.

Table 3. The Result of Current and Voltage Test

\begin{tabular}{cccc}
\hline Test & Sensor & Line Equation & Coefficient of Determination \\
\hline \multirow{5}{*}{ Voltage } & P3 C1 & $\mathrm{y}=1,608 \mathrm{x}+21,69$ & $\mathrm{R}^{2}=0,405$ \\
& P1 C1 & $\mathrm{y}=0,827 \mathrm{x}+9,456$ & $\mathrm{R}^{2}=0,623$ \\
& P1 C3 & $\mathrm{y}=0,666 \mathrm{x}+6,626$ & $\mathrm{R}^{2}=0,901$ \\
& P & $\mathrm{y}=1,847 \mathrm{x}+32,85$ & $\mathrm{R}^{2}=0,382$ \\
& C & $\mathrm{y}=0,983 \mathrm{x}+9,599$ & $\mathrm{R}^{2}=0,785$ \\
& P3 C1 & $\mathrm{y}=0,103 \mathrm{x}+0,733$ & $\mathrm{R}^{2}=0,729$ \\
& P1 C1 & $\mathrm{y}=0,116 \mathrm{x}+1,328$ & $\mathrm{R}^{2}=0,726$ \\
& P1 C3 & $\mathrm{y}=0,044 \mathrm{x}+0,535$ & $\mathrm{R}^{2}=0,383$ \\
& P & $\mathrm{y}=0,267 \mathrm{x}+1,607$ & $\mathrm{R}^{2}=0,857$ \\
& $\mathrm{C}$ & $\mathrm{y}=0,024 \mathrm{x}+0,344$ & $\mathrm{R}^{2}=0,410$ \\
\hline
\end{tabular}

\subsection{Time Response Analysis}

Time response testing is carried out with sensors that were initially not subjected to light given a light illumination of 1700 lux instantly. The test results of optical sensor time responses are shown in Figure 5 (sensor 3: 1 phycocyanin: carotene), Figure 6 (sensor 1: 1), Figure 7 (1: 3 sensor), Figure 8 (dye sensor) phycocyanin), Figure 9 ( carotene sensors) and Table 4. 


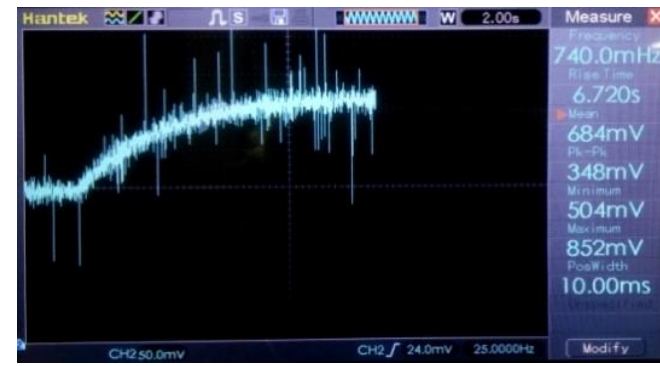

Figure 5. Response time of sample P3C1 (3:1 phycocyanin:carotene)

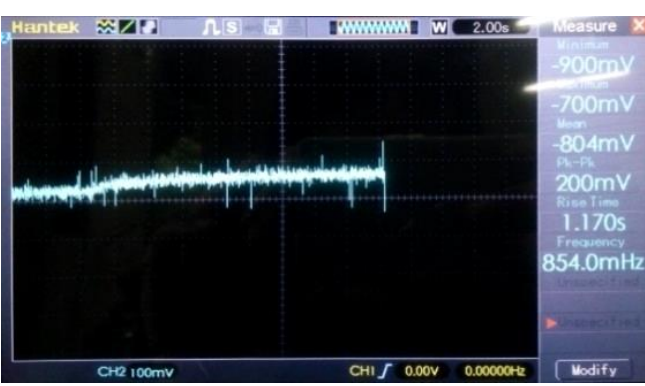

Figure 7. Response time of sample P1C3 (1:3 phycocyanin:carotene)

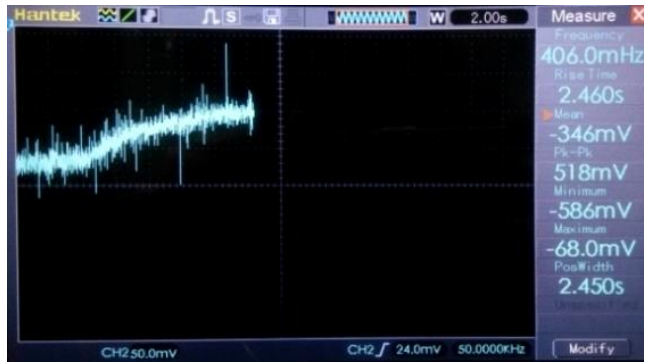

Figure 6. Response time of sample P1C1 (1:1 phycocyanin:carotene)

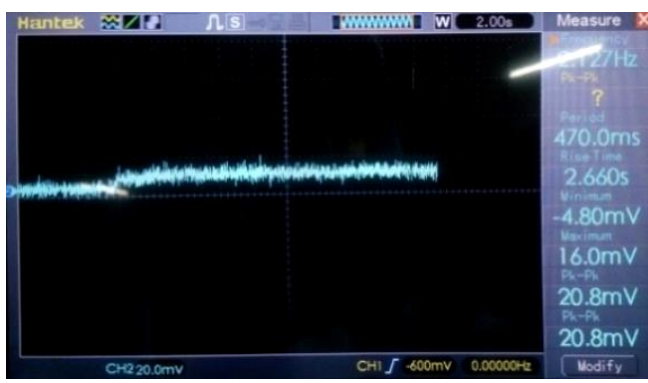

Figure 8. Response time of sample P (phycocyanin)

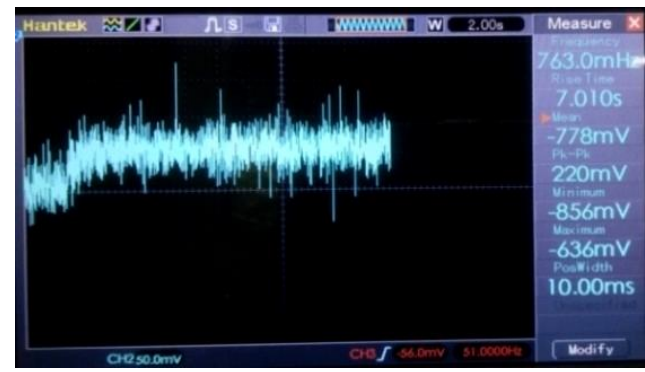

Gambar 9. Response waktu sensor sampel C (Carotene)

Table 4. Sensor Response Time

\begin{tabular}{cc}
\hline Sensor & Response Time $(\mathrm{s})$ \\
\hline $3: 1$ Phycocyanin $:$ Carotene & 6,72 \\
$1: 1$ Phycocyanin $:$ Carotene & 2,469 \\
$1: 3$ Phycocyanin $:$ Carotene & 1,17 \\
Phycocyanin & 2,66 \\
Carotene & 7,01 \\
\hline
\end{tabular}

Based on Figures 5, 6, 7, 8, 9 and Table 4, sensors that have been designed have different time responses. Sensor that use dye 3: 1 (phycocyanin : Carotene) requires 6.72 seconds to reach steady state, sensor with dye 1: 1 requires more than 1.17 seconds, the sensor with dye 1: 3 takes 1.17 seconds, a dye sensor phycocyanin requires 2.66 seconds, while dye sensor carotene takes 7.01 seconds. It can be said that the sensor with dye 1: 3 has a fast response to changes in input.

\section{CONCLUSION}

According to the results of testing and analysis in this reseach, it can be concluded design of optical sensor based on combination carotene and phycocyanin give promising result. In term of electrical parameter 
performance, the phycocyanin $(\mathrm{P})$ sensor has the highest voltage and current compared to other sensors when given a light luminance. The P1C3 sensor has the highest voltage linearity while the $\mathrm{P}$ sensor has the highest current linearity compared to the sensor others. The sensor that has the fastest response time is sensor $\mathrm{C}$.

\section{REFERENCES}

[1] Nurhayeti, " Bionanocomposites: Natural Polymer Opportunities as New Semiconductor Materials (in Bahasa)," Riset Industri, vol. 6, pp. 75-85, 2012.

[2] F. Annisa'illah, "Optical Sensor Design Using Dye and Titanium Dioxide (TiO2) Basic Materials (in Bahasa)," Skripsi, Malang: Universitas Brawijaya, 2016.

[3] W. R. Indraswari, "The Effect of Variation of Green Algae Chlorophyll Concentration on the Performance of Optical Sensors Made from Dye and TiO2 (in Bahasa)," Universitas Brawijaya, 2016.

[4] Wang Y, Pandharipande A, Fuhrmann P, "Energy Data Analytics for Nonintrusive Lighting Asset Monitoring and Energy Disaggregation," IEEE Sensors Journal, vol. 18(7), pp. 2934-2943, 2018.

[5] Pandharipande A, Caicedo D, Wang X, "Sensor-Driven Wireless Lighting Control: System Solutions and Services for Intelligent Buildings," IEEE Sensors Journal, vol. 14(12), pp. 4207-4215, 2014.

[6] Rahman MS, Haque MM, Kim KD, "Indoor Positioning by LED Visible Light Communication and Image Sensors, "International Journal of Electrical and Computer Engineering (IJECE), vol. 1(2), pp. 161-170, 2011.

[7] Kim U, Ikeda M, "A 64×64 Image Sensor with The Capability of Selective Light Detection and Background Suppression," 2017 IEEE SENSORS. Glasgow, pp. 1-3, 2017.

[8] Chiang C, "Design of a CMOS Monolithic Digitized Light Detector with Noise Insensitivity for Light Monitoring Applications," IEEE Sensors Journal, vol. 14(8), pp. 2537-2545, 2014.

[9] He X, Pandharipande A, "Location-Based Illumination Control Access in Wireless Lighting Systems," IEEE Sensors Journal, vol. 15(10), pp. 5954-5961, 2015.

[10] Diez-Gil C, "Cellulose-Based Optical Sensor for the Selective and Quantitative Detection of Mercury Ions in Aqueous Media," TRANSDUCERS 2007 - 2007 International Solid-State Sensors, Actuators and Microsystems Conference, Lyon, 2007, pp. 1429-1431.

[11] Li Z, Dong T, "High-Sensitive Hybrid Photodetector Based On Cdse Quantum Dots and Graphene for Detecting Atp Bioluminescence On Lab-On-Chip Devices," 2015 IEEE Biomedical Circuits and Systems Conference (BioCAS), Atlanta, 2015, pp. 1-4.

[12] Chiang C, Chang C, Chang C, "Design of an Ultraviolet Light Intensity Monitor for Personally Wearable Devices," IEEE Sensors Journal, 2018, vol. 18(11), pp. 4673-4678.

[13] Park H, Friedman J, Gutierrez P, Samanta V, Burke J, Srivastava MB, "Illumimote: Multimodal and High-Fidelity Light Sensor Module for Wireless Sensor Networks," IEEE Sensors Journal, vol. 7(7), pp. 996-1003, 2007.

[14] Nawabjan A, Iqbal F, Abdullah AS, "A Front Surface Optimization Study for Photovoltaic Application," TELKOMNIKA (Telecommunication Computing Electronics and Control), vol. 16(4), pp. 1383-1387, 2018.

[15] Adnan Y, Saleh K, Assaidah, "Measurement of 3 Solar Panel Output with Different Treatment Involving Controller and Reflector," TELKOMNIKA (Telecommunication Computing Electronics and Control), vol. 15(1), pp. 138-142, 2017.

[16] S.H. Pramono, et al., "The effect of photoelectrode TiO2 layer thickness to the output power of chlorophyll-based Dye-Sensitized Solar Cell (DSSC)," International Seminar on Intelligent Technology and Its Applications (ISITIA) IEEE, 2015, pp. 107-112.

[17] Muslichin, et al., "The Thickness and Firing Duration Dependence of Titanium Dioxide (TiO2) Nanoparticle Against to the Output Power of Dye-sensitized Solar Cell (DSSC)," International Journal of Applied Engineering Research, vol. 10(18), pp. 38774-38777, 2015.

[18] E. Maulana, et al., "Effect of rotational speed variation with spin coating method on $\mathrm{pH}$ sensor performance based on Titanium Dioxide (TiO2)," Sustainable Information and Engineering Technology (SIET 2017) International Conference, 2017, vol. 442-447.

[19] Rahmadwati, Sapriesty. N, Eka, A.Sabarudin, "Optical Sensor Based on Dye Sensitized Solar Cell (DSSC)," Indonesian Journal of Electrical Engineering and Computer Science (IJEECS), vol. 12, no. 2, pp. 685-690, 2018.

[20] Eka Maulana Rahmadwati, Sapriesty N, Eka A. Sabarudin, "Optical Sensor Based on Dye Sensitized Solar Cell (DSSC) with Tobaco Chlorophyll," TELKOMNIKA (Telecommunication, Computing, Electronics and Control), vol. 17, no. 4, pp. 1693-6930, 2019.

[21] Pramono Sholeh, Eka Maulana, "Characterization of Dye Sentised Solar Cell (DSSC) based on chlorphyll dye," Journal of Applied Enginerring Research, vol. 10, no. 1, pp. 193-205, 2015.

[22] Prima, Eka Cahya, "Studi Perfomansi Natural Dye Sensitized Solar Cell Menggunakan Fotoelektrode TiO2 Nanopartikel," Thesis, Bandung: Institut Teknologi Bandung, 2010.

[23] Khoiruddin, "Ekstrak Beta Karoten Wortel (Daucus Carota) Sebagai Dye Sentisizer pada DSSC," Skripsi, Surakarta: Universitas Sebelas Maret, 2012.

[24] Richmond A, "Spirulina," In Borowitzka MA, Borowitzka LJ (Ed) Microalgae Biotechnology. England: Cambridge. pp. 85-121, 1988.

[25] Tietze HW, Spirulina Micro Food Macro Blessing, Ed ke-4. Australia: Horald W. Tietze Publishing, pp 8-10, 2004.

[26] Supu Idawati, "Effects of Phycocyanin from Spiralina Platensis Microalgae as Light Harvesting on Anatomy TiO2 Nano Particle Solar Cells (in Bahasa)," Thesis. Bogor : Institut Pertanian Bogor, 2014.

[27] Bolton W, Instrumentation and Control Systems (in Bahasa), Jakarta: Erlangga, 2006. 